\title{
The Upper Bourgeoisie Education of the Greek Diaspora in Egypt in the Late 19th Century Through Penelope Delta's (1874-1941) Literature
}

\author{
Alexia Orfanou \\ School of Education, National and Kapodistrian University of Athens
}

\section{Doi:10.5901/ajis.2015.v4n1s1p13}

\begin{abstract}
The aim of this study is to understand the education of the upper bourgeoisie in the late 19th century, focusing on the education of the upper bourgeoisie of the Greek diaspora in Alexandria, Egypt. This research evaluates the educational content, practices, purposes, and ideals within this context. This study uses, as research data, the literature work of the author Penelope Delta (1874-1941), daughter of Emmanuel Benakis, a wealthy merchant of the Greek diaspora in Egypt. Her autobiographies and novels describe the education of her family's children; in the late 19th century, the Greek upper bourgeoisie's education was primarily a home education. Nurses and governesses, from foreign West European countries, were hired by the families for their children's education, with the main aim of learning foreign languages. When the children became older, private tutors were of great importance. Female education was continued at home, and male education in private schools, typically in foreign educational institutions. The emphasis for the children's socialization was on good social behavior and discipline. The findings of this study show that the upper bourgeoisie invested in education in a systematic way. Education, for this leading social elite, was part of its social identity and contributed to its distinction from other social groups.
\end{abstract}

Keywords: Late 19th Century, Upper Bourgeoisie Education, Homeschooling, Egypt, Greek Diaspora

\section{Introduction}

During 1870-1908, Greece from the early forms of capital, like trade and shipping, passed to a rapid industrial development. The industrial output became forty times greater (Milios, 2000). The social elite of upper bourgeoisie was formed and developed in harmony and cooperation with the state and even as an extension of the state itself (Veremis \& Koliopoulos, 2006). The Greek state favored private enterprises through tax reliefs and state benefits. Also, the government granted to certain banks the publishing right in different areas of the country. Upper bourgeoisie was linked to the state power through social and political networks of patronage and attraction of votes (Dertilis, 2010). This social elite was characterized by a high degree of internationalization, due to the highly developed foreign trade and the country's entanglement with Greek diaspora's capital (Milios, 2000; Tsoukalas, 1992).

The culture of the Greek diaspora's bourgeoisie was characterized by differences because of its large geographical distribution. The deeper cultural contradiction remained this of the West and Ottoman East Greeks (Dertilis, 1991). In the late 19th century, the Greek upper bourgeoisie of the Ottoman Empire was a powerful economic elite, constituted by wealthy merchants who controlled the import and export trade of Istanbul, the money market and major private and public companies. They socialized with European immigrants. As music fans, they attended, with enthusiasm, performances of foreign opera troupes and theatrical performances of foreign theater companies. They often travelled abroad for economic affairs or for leisure. Cosmopolitanism was the main feature of this elite (Stamatopoulou-Vasilakou, 1994). In Lesvos, an Aegean island under Ottoman rule, in late 19th century, the enrichment of upper bourgeoisie was due to oil trade, financial activities, companies with sophisticated equipment and trading houses with branches abroad (Sifnaiou, 1996). Greeks from Lesvos emigrated, mainly after 1850, to Egypt, Istanbul, Romania, India, Great Britain, France and elsewhere, and engaged in great commercial and banking businesses (Taxis, 1909; Vlachou, 1991).

In the late 19th century, this "powerful economic, business class" of the Greek upper bourgeoisie of diaspora was "formed by the leadership team of a few dozen families, who originated mainly from the islands of the Aegean and Ionian sea. These families stretched their businesses to trade and shipping in the Black Sea ports, Western Europe, America, India and Asia, creating multinational business networks" (Kardasis \& Harlafti, 2006, p. 53). Of main importance, was Greek diaspora of the Chios Aegean Island: "the business network of Greeks from Chios, consisted of about sixty families, which trafficked grain, cotton and wool from the Eastern Mediterranean and the Black Sea to Western Europe, and textiles and yarns from England to the Eastern Mediterranean. The main nodes of this network were Great Britain 
and the Black Sea, with intermediate branches in the Mediterranean: Marseilles, Livorno and Trieste, in the cotton markets of Alexandria and Cairo, the shipping center of the Aegean, Syros, the financial centers of the Eastern Mediterranean, Istanbul and Izmir" (Kardasis \& Harlafti, 2006, p. 55).

In Egypt, many of the wealthiest merchants were from Chios, which was destroyed in 1822 by the Turks, after participation in the Greek National Revolution. During the 19th century, Egypt was one major outlet for Greek immigrants, mainly from the Aegean islands (Clogg, 2003). Emmanuel Benakis, a magnate merchant of the Greek diaspora in Alexandria, married Virginia, who originated from the wealthy merchant family, Choremi. Both families originated from Chios (Tomara-Sideris, 2004). "The trading house 'Choremis-Benakis and Co.' was founded in 1863 to exploit the sudden upsurge of the cotton trade in Egypt, in the period of the American Civil War. It was, beyond any competition, the largest company of Greek cotton merchants in Egypt. In Liverpool, where one strong Greek community existed as in Manchester, this commercial firm was represented by the company Davis-Benakis and Co" (Clogg, 2003, p. 102). Dovetailing with British economic interests, the favorable situation of the American Civil War and later the establishment of British colonial control classified Greek families, like Choremi and Benaki, among the wealthiest families of the country. During 18901900, only the exports of Egyptian cotton reached 150 million francs, while the total export trade of Greece was lower than this amount.

The Benakis family settled in the newly constructed and privileged residential suburb of Alexandria, 'Quartier Grec' (Trimi-Kyrou, 2003). The Urabi Revolution, in 1882, contributed to the establishment of this famous 'Quartier Grec', an 'autonomous city' in Alexandria (Tomara-Sideris \& Theocharis, 2008), and the dominance of the British. In Alexandria, the Greek community's elections of 1884 highlighted the favoritism to British, group of Zervoudakis, Salvagos and Benakis at the side of Rallis and Averof. E. Benakis and members of the families Salvagos, Zervoudakis and Rallis, participated in the Board of Directors of the National Bank of Egypt, which was the largest stock exchange agency in Egypt.

Salvagos, Rallis and Benakis were connected, also, by family ties. Within the upper bourgeoisie the main marriage practice was the intermarriages. Also, the phenomenon of inbreeding existed, i.e. Antony Benakis, son of E. Benakis, married his cousin (Tomara-Sideris, 2004; Tsirkas, 1983). Similarly, in Lesvos, 'wedding strategies' contributed to the preservation and expansion of economic and social benefits of the upper bourgeoisie (Sifnaiou, 1996). It is aptly argued that the marriage strategies, within the Greek upper bourgeoisie, contributed to the "existence of close family relationships, with which were connected the members of the dominant core financial factors" of Greece, of the Ottoman Empire and of Greek communities of the diaspora (Tsoukalas, 1992, pp. 247-249). In American society of 19th century, it is also noted, that social networks "often strengthened by family ties, formed the basis for the construction of social institutions, which, in turn, could organize and reorganize public space and embed bourgeois culture into the broader American society" (Becket \& Rosenbaum, 2010, p. 2). Greeks of diaspora in Egypt were organized in communities. The first Greek community of Alexandria was founded in 1843. E. Benakis succeeded K. Salvagos as president of the social organization named 'Greek Community of Alexandria' until 1911 (Tomara-Sideris, 2004).

Greeks of the diaspora were always travelling between Athens and abroad (Dertilis, 1991). In Greece, the reform efforts of Greek Prime Ministers Ch. Trikoupis and E. Venizelos, facilitated the inflow of capital from the Greek diaspora into new business activities and public works (Veremis \& Koliopoulos, 2006; Tsoukalas, 1992; Loukatos, 1994). "The sudden, at that time, and massive invasion of Greek capitalists of the diaspora can be attributed to the conversion of the internal market [...] especially in this period, caused radical transformations within the Greek bourgeoisie diaspora, which are due to one very general process: the transition from capitalism to the stage of imperialism" (Tsoukalas, 1992, p. 251). Emmanuel Benakis, an upper bourgeois of diaspora, gradually was added to the upper bourgeoisie of Greece (Veremis \& Koliopoulos, 2006). He was closely linked to the modernization policy of Eleftherios Venizelos, who in 1910 appointed him at the Ministry of Economy (Clogg, 2003). Similarly, in the 19th century America, an upper bourgeoisie economic elite "wielded enormous political power, swaying legislators in their favor and defining agendas of political parties" (Becket \& Rosenbaum, 2010, p. 1).

The social stratification of the Greek immigrants in Egypt included labourers, a sizeable bourgeoisie, mostly "lower middle' and 'middle', and only 60-70 families which formed the upper bourgeoisie (Tomara-Sideris, 2004). It is aptly argued, that "the upper bourgeoisie elite traders and stockbrokers, although in relation to the entire Greek population were less numerous, they strongly influenced not only the immigrant communities worldwide but the entire Hellenism. [...] This widespread elite, which practices resale business, includes many people with properties that far surpass the total national income of the country of origin" (Tsoukalas, 1992, pp. 343-344). 


\subsection{Research Methods}

\subsubsection{Research purpose}

The purpose of this study is to define the education of the Greek upper bourgeoisie of diaspora in Egypt. Firstly, focuses on political, cultural and social ideals through which the educational ideals emerged. Other questions came up: What were the key concepts which defined this education, the types of training employed and the daily practice? How were the educational area and the time organized? What courses were taught? What were the differences between female and male education? What kind of social behavior was taught and how was the student discipline defined?

\subsubsection{Procedure}

In this paper combined research methods were used, the historical hermeneutics (Cohen \& Manion, 1994) and content analysis (Berelson, 1952; Kyriazi, 2011) of literature work, novels (Lidbury, 2013; Santos, 2005) and autobiographies (Jensen-Wallach, 2006; Symonolewicz, 1944) considered with their limitations.

The determination of upper bourgeoisie's education, characterized mainly as 'homeschooling', has to confront the lack of official research data. It is aptly argued that literary texts can be a valuable source for the history of education. Literary texts, despite the ambiguity of subjectivity, can be used as unique personal testimonies where there are no other historical sources (Malafantis, 2005). It is also, aptly argued that "typical facts, [...] general conditions, the external and shared experiences of groups in many matters (such as family and institutional life - schools, churches, friendship groups, clubs and organizations): these aspects of life are reflected with considerable reliability in literature. The historian cannot accept uncritically the portrayal of such matters, but if the author, including them has proved to be a solid witness, or if many authors representing different subgroups and attitudes agree with their presentation of similar things, then I am convinced the historian can and should add such evidence to that of other sources in his construction of a picture of the past. Here literature provides data in the same way as other 'soft' sources" (Skårdal, 1984, p. 79).

In this research, literature was used as historical source material. Four autobiographies of Delta, were used as memoirs-biography, primary sources (Cohen \& Manion, 1994): 'Raw Remembrances', 'Memories 1899', 'Memories 1921' and 'Memories 1940'. Quotations from the autobiographical books were fitted together. And quotations from the author's novels, which present her childhood memories and meet her personal narratives of her life story (McAdams, 2008), were compared and verified by the information effectively drawn from her autobiographies in order to increase the credibility of the findings.

\subsubsection{Author}

Penelope Delta (1874-1941) was daughter of E. Benakis. This lady of the Alexandrian upper bourgeoisie was a popular writer (New guide of biographies, 1979; Navet-Grémillet, 1998; Navet-Grémillet, 2006). Her literature work in Greek is in the demotic language (Vitti, 2008). She cooperated with other people in favor of educational demoticism (use of popular/demotic language) in Greece. She integrated into the 'Aderfato of the National Language' (National Language Society), an association founded in Istanbul, for the prevalence of the demotic language (Papakostas, 2000), in 1907. In 1910, she became a member of 'Educational Association' for the educational reform in Greece and the prevalence of demotic language in education (Zannas, 2009). She was also involved in reading books in the demotic language in the elementary school in Greece (Dimaras, 2006).

Delta was a pioneer of children's literature (Vitti, 2008). She wrote pedagogical books that appealed to parents and teachers. She wrote, also, historical novels (New guide of biographies, 1979) with main subject her contemporary history. She "collects and examines files, personal testimonies, memoirs. Collects newspaper clippings, brochures, photographs" (Zannas, 2009, p. 9). She, also, authored autobiographies (New guide of biographies, 1979). The diary is a literary genre appropriate for introspection and secret emotions. Delta often rushed to the calendar recording of personal incidents. The active participation in the historical events of her country and her secret anxieties are presented in different calendar notebooks (Vitti, 2008). Delta was born in 1874, and spent her childhood in Egypt with short breaks. In 1876, her family moved for two years in Liverpool. In summer 1877, the family travelled to Chios. In 1879, they stayed, for their first summer, in Castella of Piraeus. The summer of 1880, they travelled to Gratz of Austria. In summer 1881, also, to Piraeus. In 1882, they moved temporarily to Athens due to the Urami revolt. They returned to Alexandria. In 1883, because of cholera in Egypt the family remained for a few months in Athens. In 1886, they travelled to Chios. In summer 1889, 
Benaki's family travelled to Paris, Liverpool and Wales. In 1891, the 18-year old Penelope entered adulthood and the secular life of Alexandria. She got married in Alexandria, in 1895. The author had three daughters, Sophia born in 1896, Virginia in 1897 and Alexandra in 1900. In 1906, the author, with her family, settled in Frankfurt. They returned to Alexandria in 1913 (Zannas, 2009). World War I affected their choice to leave Frankfurt, where they lived due to business reasons (Zannas, 2008). In 1916, the family left Alexandria for a permanent settlement in Athens (Zannas, 2006).

Delta's childhood memories are from Greece, Athens, Chios and Europe (Tselika, 2004), but mainly from cosmopolitan Alexandria (Navet-Grémillet, 2006). Delta, in her literature work, describes her contemporary history, her family history and personal life. She achieved to portray the Greek upper bourgeoisie lifestyle and ideals, in the late 19th century (Zannas, 2006; Kouzeli, 2005). It is stated that "Egypt's natural and social environment had a significant impact on Egyptian-Greek literature" and "this influence was largely mediated through the structures of British colonialism". "Under the triple influence of the Greek language, Egyptian land and the British Empire, the formation of a distinctive Egyptian-Greek identity was a matter of vital concern for Egypt's Greek writers" (Tziovas, 2009, p. 189). Delta was also, influenced by the cosmopolitan center of Alexandria and colonialism. Her novel 'Mangas' "is not uncritical of British colonialism". It is worth noting that finally, 'Mangas' left Alexandria and came back to Greece (Tziovas, 2009, p. 188), as the author did.

\subsubsection{Literature}

Eleven books of Penelope Delta, which contain information on education were used:

a) Four autobiographies:

1. 'Raw Remembrances', written approximately between 1931-1932 and first published in 1980 (Delta, 2008). This autobiographical text contains, also, the unpleasant events of childhood (Zannas, 2006). The trilogy 'Memories':

2. 'Memories 1899', written approximately, between 1931-1932 or later and first published in 1990 (Delta, 1994).

3. 'Memories 1921', written approximately between 1921-1930 and first published in 1996.

4. 'Memories 1940', written between 1940 and 1941 and first published in 2007 (Delta, 2007b).

b) Five novels:

The trilogy 'Romiopoules' (Young Greek Girls), an autobiographical novel for adults, written between 1927 and 1939 (Delta, 2008).

5. 'To Xypnima' (The Awakening), volume 1.

6. 'H Lavra' (The Heat), volume 2.

7. And 'To Souroupo' (The Dusk), volume 3 (Delta, 2014).

8. 'Trelantonis' (Crazy Antony), first published in 1932 and dedicated to her brother Antony childhood adventures. This children's novel describes pleasant childhood memories of a summer stay in Castella of Piraeus (Zannas, 2006), in 1881 (Zannas, 2009).

9. 'Mangos (Crafty), a children's novel, first published in 1935, with narrator a dog named 'Mangas' (Delta, 2013).

c) Two pedagogical books:

10. 'The irresponsible or Children's Souls', first published in 1921 and

11. 'Reflections on the Upbringing of children', first published in 1911 (Delta, 2008), in 'Deltio', the periodical edition of 'Educational Association' (Zannas, 2006).

\section{Findings}

\subsection{Upper bourgeoisie's investigations in education}

\subsubsection{Foundation and maintenance of Community's Greek schools}

Upper Greek Bourgeois in Alexandria, as Averof, Antoniadis, Zervoudakis, Benakis and Salvagos, built schools with large amount of money donations (Tsirkas, 1983) and funded their maintenance (Tselika, 2004): a) in their place of origin, i.e. the donation of family Choremi to the Agricultural School of Chios. b) In Greece, i.e. the donation of family Choremi to the Athens College (Tomara-Sideris, 2004). c) In Egypt, i.e. in Alexandria "under the sponsorship of Tositsa brothers and 
Stournara family, the first organized and operated institutions were the Greek Hospital (1817) and the School of Greeks. After the establishment of the Greek Community, [...] the existed institutions were further developed and new were established" (Topis, 2002, p. 160). Over time, the educational needs of the Greek diaspora increased. In 1878, a second class was added in the high school of Alexandria, which, in 1890, was recognized, as a four-year (classes) school, from the Greek State (Leccou, 2001). Several schools were founded by donations: Tositsaia School (1854) (Tselika, 2004), Averof School for Girls (1894), Salvagos Trade School (1906), Pratsikeios Primary School (1907), Zervoudakeios School (1907) (Topis, 2002) and Averof High School (1909) (Tselika, 2004). In 1907, Emmanuel and Virginia Benakis donated an Orphanage for Girls, which offered education as well (Topis, 2002), and began operating in 1909 (Tomara-Sideris, 2004). In Caire, Ambetios School (1860) was founded by donations, (Tomara-Sideris, 2002 \& 2007).

\subsubsection{Emphasis on their children's education}

Although upper bourgeois, made donations to the Community schools, they choose private education for their children. It is noted that "consolidation and distinction, of course, were never completely fixed states of bourgeois being. Formulating a sense of themselves as a distinct social group with shared identities, while simultaneously setting themselves apart from other citizens, was an extended and continually negotiated process" (Becket \& Rosenbaum, 2010, p. 2).

P. Delta reports that: "I had to become 17 years old to acquire my own judgement [...] to feel gratitude to my parents. Who, although, did not have the means when they were children, to grow spiritually, they were submitted for expenses and deprivation, in order to provide us our 'teachers' ". She states that due to their education they "grew spiritually, experienced the enjoyment of reading and the ability to cultivate themselves and to ascend to higher realms" (Delta, 2008, p. 143).

\subsubsection{Focus on scholarships for studies}

Greek upper bourgeois, adopted an education which distinguished them from other social groups and also, functioned as a mean for maintenance of their social distinction. However, "the types of channel that are privileged by elite groups to reproduce their social position, and the degree of social closure or openness of these channels to other groups" are significant (Van Zanten, 2010, p. 329). On that issue, we should notice, regarding Emmanuel Benakis, that "his social and intellectual position helped him to encourage, by any means, learning and knowledge, not only for his own children, but also, for others, by providing large amounts of money for student scholarships, as well as for scientific research" (Tselika, 2004, p. 63).

\subsection{Upper bourgeoisie favored private education}

In the late 19th century, although, Greek Community schools existed in Alexandria (Leccou, 2004; Hadjifotis, 1999; Gialourakis, 2006; Kitroeff, 2010; Tomara-Sideris, 2007), Greek upper bourgeois preferred homeschooling and private institutions.

\subsubsection{Upper bourgeoisie 'estimation' on Greek Community Schools}

Michael Tositsas was declared the first consul of Greece in Egypt, with his base in Alexandria, in 1833 (Topis, 2002; Karanasou, 1999) and the first president of Greek Alexandrian Community, founded in 1843. "He managed to reach the jurisdiction of the Greek government and put under the protection of the General Consulate of Greece all the Community institutions, along with the entire community organization. In contrast to what was implemented until then in the Ottoman Empire, where communities, schools and charitable institutions were subject to the jurisdiction of the Ottoman government and under the Ecumenical Patriarchate supervision. Thus, the Patriarchate of Alexandria became a spiritual and religious authority of the Greek diaspora in Egypt, but did not have jurisdiction over the Community law and its institutions. The example of Alexandrian Greek Community, was followed by all Greek Communities established later in Egypt" (Tomara-Sideris, 2004, p. 41; Karanasou, 1999). The goal of the communities was the implementation of their educational needs. "The whole concept and treatment of the educational issue in Egypt, resembles to the function of primary school of the Trikoupian period in Greece. ('Schools of the municipality', which i.e. were under the responsibility of the local municipal authority)" (Tomara-Sideris, 2004, p. 45; Karanasou, 1999). Thus, the organized communities of Alexandria and Cairo functioned as state mechanisms (Tomara-Sideris, 2004). 
Delta states that: "the Greek schools of the community were considered and in fact were not still efficient, during those years" (Delta, 2008, p. 147). "The schools of the Greek community in Alexandria, the most important in Egypt, did not have any good teachers. They were so inferior, that the children of wealthy families did not go there. The teachers, sent by the Greek state, were of such bad quality and level, that the families did not dare to entrust their children to them. I remember, our mother saying repeatedly: -"I prefer my girls being illiterate than trusting them to the Community girls school". That was the way, all Greek parents were thinking of their girls and boys. They sent their children to foreign schools, 'Frères' and Jesuits. [...] In my time, boys and girls avoided Greek schools, and many families, which didn't have the financial means to educate their girls at home, sent them to Catholic nuns, 'Soeurs de St. Vincent de Paul', 'Mères de Dieu' and 'Soeurs de Lion'. At the time, a whole army of Catholic priests and nuns invaded Egypt" (Delta, 2008, pp. 197198).

\subsubsection{Private or foreign schools for upper bourgeois}

In the late 19th century, upper bourgeois boys studied in private schools, in Egypt or abroad. Usually, they followed studies in the Universities of Europe.

Constantine Kavafis, in 1881-1882, studied in Alexandria, at the Commercial-Practice School, 'Mercury' of Constantine Papazi, who became Doctor of Philology of the University of Erlangen, in 1877 (Tsirkas, 1983). Antony Benakis, born in 1873, studied firstly in Papazi's school, then for two years in Voulgari's, in Athens (Delta, 2008, p. 147). In 1882, when he was nine years old, went to the boarding school of Voulgaris (Delta, 2008, p. 81). Delta, in 'Trelantonis' displays the scene where his parents, with other relatives, announced him, his studies in Athens. His mother wept. "His father put things in place. [...] At school he will learn a world of things and will have classmates and friends." The family expected from him to learn how to cultivate self discipline at first, to develop good social behavior, and to be more prudent, because he was a bit naughty. "But at school all this would be corrected. [...] -All Boys need school. It builds character" (Delta, 1980, pp. 243-244). After Boulgari's school, Antony studied in Jesuits of Alexandria (Tselika, 2004), since 1884, he had lunch there and returned home late in the afternoon. But, in this school a proselytizing issue emerged and he stopped attending. At the age of fourteen he went to England as a boarder (Delta, 2008). During 1887-1891, he studied in College Rossall's, near Liverpool (Tselika, 2004, p. 75). Many Greeks of diaspora in Egypt "sent their children to foreign schools in order to obtain a recognized high school diploma, or to study foreign languages which were very important in Egypt" (Leccou, 2001, p. 48). Alexander Benakis, born in 1878 (Delta, 2008), went to a boarding college in Switzerland, in 1893 (Delta, 1994). Aristides Choremis, born in Alexandria in 1876, got the graduate certificate of secondary education from Geneva and continued his studies in Manchester with specialization in cotton. The cosmopolitan Greek diaspora in Egypt evolved and flourished within the global system of the European colonial domination and was oriented in European capitals (Tomara-Sideris, 2004).

Similarly, the upper Greek bourgeoisie of Istanbul, usually, studied in Western European capitals (StamatopoulouVasilakou, 1994). Also, upper bourgeois of Lesvos were "cosmopolitan, educated, spoke fluently French, Russian, Italian and English and spent their holidays or went for honeymoon in Europe. [...] Businessmen sent their sons at Marseilles for business studies, in Berlin and Paris to study medicine, in Italy and Germany to study literature, law and chemistry. [...] Their choice of studies was not random. In order to create real industrialists, besides the funds, they should also have, the necessary scientific knowledge" (Sifnaiou, 1996, p. 323). The monks owners of the Commercial "Collège Saint-Louis de France', in its first establishment in Mytilene in 1901, realized that the local upper bourgeoisie "will continue as before to send their children to the prestigious schools of big cities, even in Europe. [...] The social status has an important role in the East. The family announces proudly everywhere: our child is studying in Cadi-Kewy, in 'Robert College', in Lausanne, etc. Who would dare to confess publicly that his child is studying in Mytilene. The major urban centers attracted more students in the East than elsewhere. [...] Families, which could afford the expenses for boarding schools, send their children, preferably, in large schools of Constantinople, Smyrna, Thessaloniki etc." (Archives des Frères Maristes, 1911). It is believed that "studies of elite education have underscored the common features of elite educational institutions, that distinguishes them from other institutions that look after young people from the same age cohorts" (Van Zanten, 2010, p. 329).

\subsubsection{Homeschooling}

Since the 18th century, instructors of all kinds have left Neuchâtel in order to work as school teachers in Switzerland, 'précepteurs' and 'gouvernantes' for families of German, Dutch, English and Russian nobility. In the 19th century, the 
exportation increased in 'bones d' infants who went to work in bourgeois families across northern and southern Europe (Maeder, 1993). The governesses educated children in the royal courts, children of the dukes and bourgeois (Bayley, 2014). In the late 19th century, homeschooling was a common practice and compatible with Victorian era: "The governess is a familiar figure to the reader of Victorian novels" (Peterson, 1970, p. 7). The Victorian governess novel is a specific genre of novels (Wadsö-Lecaros, 2001). In 18th and 19th centuries, the jobs of governesses, guardians, chaperons and nurses were mostly widespread in life and in novels (Murinová, 2007). Delta in her novel 'Mangas' mentioned 'Mademoiselle' and 'Miss' as teachers and a piano tutor (Delta, 2013). In 'Romiopoules' she also mentions, a mother who carried out for the children a home schooling program and had tutors (Delta, 2014b, pp. 214-215): a German tutor Fraulein, a French tutor, a Greek governess who lived with the family, a piano tutor and another one for dance lessons (Delta, 2014c).

It should be noted that, in order to have a complete idea of the Greek education, we should take in consideration that homeschooling, for certain categories of families, was the obvious solution for their education (Terzis, 2010). In Greece, homeschooling was so widespread, in 1877, that 'Estia', a popular magazine of Athens, published the article by J. Russel: "Should young people be educated at home or in public schools?" This article argued that the preference should be given to the school education, because homeschooling could effectively help the learning, but not the children's socialization, as the school did (Russell, 1877). However, in 1889, many parents in Greece entrusted the care of their children at home governesses, usually, invited from Western Europe (Spathakis, 1889). The teacher I. Stavros, from Corfu, states that: "the Greek upper bourgeoisie, when the infant becomes a toddler, will not think of nothing else than how to provide the appropriate German, Swiss or English nurse. [...] I. Stavros was tutor of children of the upper bourgeoisie, brought up mainly by foreign governesses" (Stavros, 1912, p. 137).

Homeschooling was adopted by the Greek upper bourgeoisie of Istanbul, which hired governesses (Delta, 2008, p. 148). Also, in Russia, where Mademoiselle Dufay, the governess of Delta, worked previously (Delta, 2008). In Russia, for the Greek diaspora upper bourgeoisie "the educational cell was the house. All kinds of teachers come and go to provide a higher quality education than public schools. [In Odessa], the Sifnaiou boys, of the third generation of immigrants, had a teacher who came, especially, from Bucharest. And the girls were taught by French female instructors" (Sifnaiou, 1993, pp. 193-194).

\subsubsection{The Study room}

'Mangas', the dog narrates: "Poor human children! Male and female teachers, Misses and Mademoiselles succeeded, the whole day, each other in the home study room" (Delta, 2013, p. 55). Delta mentioned: "at the end of the summer, [...] we went straight to our new home in 'Quartier Grec', in 1884. Our 'school' was in the upper third floor of the house, between two terraces, one facing east and the other west, where we had the right to go out and play. [...] Mademoiselle Dufay's bedroom was on the second floor, under the study room" (Delta, 2008, p. 121). Delta states: "when I entered our study room, it seemed to me that I felt an atmosphere of superiority. The large table with the sour cherry tree baize, that covered all of it and was hanging around it. the mahogany chest of drawers, which was guarding the paint, pencils, pens, toys, sewing accessories. the libraries with the teaching books and our amusing readings, 'Girl's Own Annual', 'Bibliothèque Rose', 'Jules Verne', 'Chatterbox and others', new year's gifts or winning bets, by Constantine Choremi [...], historical books, 'Walter Scott', what a world of impressions, knowledge, thinking and dreaming! The study room window was above the main entrance of the house. It overlooked a street with trees [...]. Far from us, between newly built houses with gardens, appeared the sea [...] of the Alexandrian coast. This window was really enjoyable during the evening, when between two courses, we ate our bread and cheese, in silence or listening to any historical narrative of Mademoiselle" (Delta, 2008, pp. 143-144). Antony, who was all day at the Jesuits' school, went in the study room only for his evening study (Delta, 2008, p. 195). Delta in 'The Irresponsible' referred, also, to the study room of the main person of this short story (Delta, 1961a, pp. 45-47).

\subsubsection{2 'Domestic staff' recruited for kids}

\subsection{Nurses}

Delta mentions many English, one French and one Italian nurses in her family. She and her older sister and brother always had English nannies. Until they reached school age, they were brought up by them. Their responsibilities were children's nutrition (Delta, 1994), accompanying the children on walks and social visits, the learning of English (Delta, 
1980), supervision and discipline. Alexander, two years old in summer 1880, had a nanny from France. Later, the family for the two small children, Alexander and Argini, recruited a Catholic Italian nanny (Delta, 2008).

\subsection{Governesses}

Delta mentioned the German governess of her friends, one of the famous German Berg sisters, which worked, in all the Greek houses of Constantinople and Alexandria, and were sought after (Delta, 2008).

Greek governesses were not in the preferences of upper bourgeoisie. Delta referred to a Greek governess of her uncle, replaced by a French one: "as for the children of uncle Demosthenes, they had Greek governess, of poor quality too" (Delta, 2008, p. 147). I. Stavros states that: "the upper bourgeoisie, however, does not trust the infant to a Greek nursery teacher". He considers that it was due to lack of appreciation and confidence in the abilities of the Greek governesses and "because it is either out of habit or imitation, i.e. every woman does what her mother or sister did, or another lady of the same social elite" (Stavros, 1912, p. 137).

Finally, "uncle Demosthenes [...] decided to appoint for the children a French governess" in order to provide a better level of education for his children (Delta, 2008, p. 147). Delta, in her autobiographies, makes references to her own French governess: "When I was ten years old, my father brought from Paris one French teacher, Mademoiselle Dufay, which for us remained as Mademoiselle" (Delta, 1994, p. 6). In 1884, Victorine Dufay joined the Benaki's family as a governess (Zannas, 2009). Usually, French governesses arrived in Egypt recommended by the French consulate and the Catholic clergy. V. Dufay was recommended by Mrs. Vlastou (maiden name Ralli), a Greek of Marseille diaspora (Delta, 2008).

\subsection{Tutors}

Delta referred to Mr. Williams, their tutor for English: "we were talking, reading and writing in English, but the lessons of the old man Williams were funny" (Delta, 2008, p. 200). The children English books were Mr. Williams's choice. 'The British Girls Annual', English children book series for girls and the relevant for boys were included in the library of their study room (Tselika, 2004).

Delta also had a French tutor, Madame Mettère. She narrates that the girls of the family and the little son Alexander followed, for learning Greek, private courses at home by Greek tutors, firstly Mrs. Sofia and then Mrs. Sofia Fontrier, director of Greek Girls School of Alexandria. In 1899, in a trip to London, the role of the Greek tutor was taken by the mother of Delta. She also reports their Italian dance tutor, named Amfouzo and Mr. Karatzas, the music tutor for piano (Delta, 2008).

\subsubsection{Curriculum}

There were differences depending on age and gender of children. "Delta mentions in 'Raw remembrances' and 'Trelantonis' that the boys followed a common with girls' curriculum in early age. When, they became older "boys continued their high school studies in Greek or foreign schools" (Zannas, 2006, p. 10). For a girl the betrothal meant the end of her studies. With the betrothal of her sister, Penelope mentioned that: "First, Alexandra did not have any more courses, and I was alone in the courses and in the study, in our study room [...] Alexander still of small age, did not follow the same courses as l" (Delta, 2008, p. 195).

\subsection{Languages}

Delta lives "in a society that speaks English and French in living rooms and offices, Greek at home, Italian in the street, and uses Arabic when it is known, just to give orders (Navet-Grémillet, 2006, p. 317). Delta describes in both 'Raw Remembrances' and 'Trelantonis' a strict program of courses: Languages, Greek and foreign and general schooling. The children of Delta family were taught "foreign languages [...] and Greek, i.e. a dry katharevousa that repels children from the Greek book and the Greek language, which was essentially limited to the spoken language" (Zannas, 2006, p. 10). Delta reports that "we had just learned how to read and we read English and Greek. We hated our Greek books [...] But we devoured our English books" (Delta, 2008, pp. 27-28). She also narrates: "Our teacher was French, our spirit, upbringing, education and culture was French. Most of our books, all the teaching and most of our entertaining books, were French. The only language I learned well, was French" (Delta, 2008, p. 200). A characteristic, of the upbringing and 
the education the children of this bourgeoisie of cosmopolitan diaspora received, is that the autobiography of Delta, 'Memories 1899', is written in French and with some dialogues in English, when the author was 25 years old. The substantial contact with the Greek language will be later (Zannas, 2006).

Delta narrates that the girls of the family and the little son Alexander followed Greek private courses with Mrs. Sofia Fontrier, director of Greek Girls of Alexandria, who had a reputation of a very wise teacher, but that was all superficial, without foundation and depth, she was playing with the technological rules which she knew by heart and she threw dust in the eyes of parents, without any knowledge and without any idea of the appropriate pedagogy and teaching. Everyone, who passed through her hands, remained uneducated, misspelled and the worse, with hate for each printed or handwritten Greek book, text or letter, which reminded us the boring knowledge derived from learning by heart meaningless words and the frustrating effort we made to study and learn by heart whole pages, which we did not understand (Delta, 2008, pp. 144-145). P. Delta narrates: Antony, "I do not remember if in the afternoon, after the Jesuits' school, he had a special Greek teacher at home. However, he learned Greek, while we all, the girls and Alexander, who was small, in the hands of Sophie Fontrier, remained illiterate" (Delta, 2008, p. 147).

\subsection{Holy indoctrination}

The children studied holy indoctrination (Orthodox Christian) with Mrs. Sophia, the Greek teacher (Delta, 2008).

\subsubsection{3 'Agreeable talents'}

Delta states that with the tutors we "learned music, painting, dancing, crafts" (Delta, 2008, p. 143). The education of girls was not neglected, but was 'limited' in contrast to the one the boys received. The curriculum consisted of the development of 'agreeable talents' such as 'music and piano, painting, dancing, crafts'. It is aptly argued that in France in 18th century "for the daughters of the nobility and the upper bourgeoisie, education of agreeable talents was also important, and they consisted of competency in domains such as music, drawing, and embroidery. These skills made girls more desirable as spouses, but also, distracted women from other occupations less suited to their gender" (Kibler, 2013, p. 19). Delta states "I still continued my embroidery" (Delta, 1994, p. 261). She reports that "we knew all the dances, since we were 7-8 years old, we gathered, a group of children from every good Greek family in order to "have dance lessons', which were taking place each time in a different house during the winter afternoon. Three or four instruments accompanied the dances, and we had a tall, blonde, slender, Italian dance teacher, Mr. Amfouzo" (Delta, 2008, p. 167). And Mr. Karatzas, the music teacher taught piano to Penelope and Alexandra (Delta, 2008).

\subsection{Housekeeping occupations}

Delta describes in 'Raw remembrances' and 'Trelantonis' that when the girls became older "their education in music and mainly household was completed. The model of the housewife, with the least necessary knowledge for social reasons, is dominant in female education of the era" (Zannas, 2006, p. 10). Especially, for Delta's mother household was the primary, or almost exclusive work for women (Delta, 2008). She narrates: "My days were very monotonous: in the morning as I got up early, I managed to read a little and then I studied. After eight, I keep sewing until lunch time. Sewing was done exclusively at home, except my dresses and all my girlish life was spent with sewing. In the evenings, often, I went out with my sister or I made social visits with my mother" (Delta, 1994, p. 20). In her autobiographical novel 'Romiopoules', she writes a dialogue between a mother and a daughter. The mother states: "The ornament of woman is the household" (Delta, 2014a, p. 13). Delta narrates that "Mademoiselle watched with dissatisfaction the housekeeping occupations, which, often, interrupted the course" (Delta, 2008, p. 142).

\subsection{Children's socialization and emotional development}

In 'Romiopoules' Delta states, with consciousness for her own social class "We, the high society, are probably spoiled by foreign influences of teachers and readings" (Delta, 2014c, p. 442). However, she approves, the need of a distinguished education that the high society needs "But as we go to so-called higher social classes, parenting becomes more complex. [...] So we are not prepared, as it was needed, to give to our child the complicated upbringing required in higher classes, similar to his spiritual development. That is, why we find among us many people with intelligence, education and knowledge - but not with character" (Delta, 1961b, p. 204). 


\subsubsection{Instructors, children and national stereotypes}

The 19th century was the age of nationalism which led to stereotypes of countries and of foreign governesses, English Miss, German Fräulein and French Mademoiselle. These stereotypes affected visitors and hosts (Bayley, 2014; Anagnostopoulou, 2005). Delta states that foreign governesses and tutors underestimated Greek people: "Mademoiselle Langlois spoke for the home and her Greek bosses with the same contempt of Mr. Williams and other foreign tutors" (Delta, 2008, p. 147). Delta reports that "the French lesson was a delight. I understood it and enjoyed it. I was learning in contrast to the Greek katharevousa language. While the Greek lesson was all about parroting. And this was another reason to feel racial inferiority" (Delta, 2008, p. 144). Mademoiselle Dufay commented the Greek teacher and contemptuously told to the children "Qu' est ce que c' est que ces leçons, de Mademoiselle Sophie!" (Delta, 2008, p. 145).

In Greece, in 1889, it was believed that home governesses from Western Europe could teach successfully some foreign languages, or piano, or dancing, etc. But it was better to prefer Greek governesses, as 'homogeneous' and of the same religion (Spathakis, 1889). The teacher I. Stavros considers that foreign governesses did not indoctrinate children, of upper bourgeoisie, according to the principles of Greek family and 'Greek National Union', but pursuant habits and flaws of their foreign homeland (Stavros, 1912, p. 137). In the homonymous novel, 'Mangas', the dog, narrates: "And also, I don't love Miss, not so much because she was skinny and had big teeth, but because, like Mademoiselle she smells foreign" (Delta, 2013, p. 55). Delta, in her autobiography reports: "The arrival of Mademoiselle Dufay at home is another landmark in my life. We were predisposed against her, because she was French, 'frog-eater', as our English male teacher said with contempt for every Frenchman" (Delta, 2008, p. 118). In addition, Delta presents negative stereotypes for foreign instructors: "wretched, bad, bonnes pour l' exportation". However, finally, she speaks for her own governess positively and even with enthusiasm: "Mademoiselle Dufay was, for our good luck, an exception. [...] She was a real finding. Advanced age, moral woman, God-fearing, devout Catholics, never attempted to convert us to the Catholicism, nor drag us to the Church and religion" (Delta, 2008, p. 148). Religion also, differentiated people. P. Delta in her "Reflections on the Upbringing of children" states "she had a foreign protestant teacher, from those who talk a lot about religion with children (Delta, 1961b, p. 211).

\subsubsection{Punishment as an educational mean}

The aunt of the children, because of bad behavior to their nanny, forbade them to eat fruit at lunchtime and in the evening. She asked Alexander to stand in a corner against the wall as a punishment, and Anthony to go to the attic and stay there until lunchtime (Delta, 1980, p. 42). For bad behavior, Penelope reports that her mother: "slapped me, forbade me to go out with others and sent me to do my homework throughout the rest of the afternoon" (Delta, 1994, p. 5).

The Greek teacher Sophia was beating the children (Delta, 2008, p. 45). Penelope reports that "When I was nine years old, my mother beat me mercilessly because I smeared my notebook for French courses" (Delta, 1994, p. 5) and she did not study her French lesson. This day, the mother asked her to eat in the study room and not with the others in the dining room (Delta, 2008, pp. 98-99).

She mentions for her governess that "the three bigger children and the just six years old Alexander, were under the supervision of Mademoiselle Dufay who disciplined us. [...] When she said something, we had to obey immediately. She rarely scolded us [...]. But she imposed herself to us with a discourse, with a nod. She recognized the severity of our parents and had put a rule not to increase our punishments, but through persuasion and love she was by our side and guided us. And she achieved this from the first day" (Delta, 2008, pp. 119-120).

\subsubsection{Parents, children upbringing and emotional development}

Especially, in 'Raw remembrances' the distance between parents and children was impressive (Zannas, 2006). The comfortable life of the children of the bourgeoisie was accompanied by the absence of parents. "In the 'happy' families the gap between parents and children was even greater and parents spent with their children even less time than they do today" (Pilbeam, 2009, pp. 160-161). In 'The Irresponsible' the mother kisses their children only twice a day, in the morning and in the evening (Delta, 1961a, p. 35). "In the morning the kids were dressed, and fed and went to say hello to their parents' room. The father who usually was reading the newspaper- hastily said good morning to the children and continued reading. Mother [...] kissed children in order, starting always from the older, with a standard, uniform kissing. at night she gave them another similar kiss, when kids were saying Goodnight at bedtime, and that was the caress of the 
day, "because children should not know how their parents love them". [...] Then, kids went to their lesson" (Delta, 1961a, p. 37).

Delta argues that in the books "always mothers embraced, kissed, caressed, loved their children. After any scolding or cop, we always have the same question: Why only in books mothers love their children, and in life they do not?" (Delta, 2008, pp. 27-28). "Delta is described in both, 'Trelantonis' and 'Raw remembrances' her childhood. [...] Penelope grows in a strict family environment: paternal and maternal power imposed hard, mainly by fear and lack of any understanding and contact between parents and children. And as the distance is unbridgeable, the love of the delicate child is received by another person, out of the family, the outlandish teacher. In the case of Delta, Mademoiselle Victorine Dufay, was a lifelong friend" (Zannas, 2006, pp. 10-11).

Delta reports for her brother: "as I remember, Antony never complained of the lack of love in our family. [...] I asked him: "You do not admit that our upbringing, although graceless, it builds character? With discipline?" - "No", he repeated softly. [...] "It was ugly, drained and dry." [...] He was hurt just like me, by our upbringing, without love and tenderness" (Delta, 2008, pp. 175-176).

\subsection{The education of the generation of Delta's daughters}

Delta, in her autobiography, describes the education of her daughters, born in 1896, 1897 and 1900. In 1906, Delta lived with her French governess Victorine Dufay and she states that the Austrian female tutor had left. The girls were taught by female tutors (Delta, 2007a).

\subsubsection{Homeschooling and partial school attendance in Frankfurt}

During 1907-1913, her family immigrated to Frankfurt. The education of her daughters in Frankfurt was described as partial attendance at a school, only for "some hours a week" (Delta, 2007a, p. 319).

In Frankfurt, the school attendance was completed by homeschooling. On February 1907, Penelope traveled to Frankfurt, to be settled there, with a female tutor (Delta, 2007a, p. 287). Also, "a Greek female tutor" is mentioned, who lived with the family. She went from Greece to Frankfurt for this purpose, in summer 1907. She was described "with a bouffant hair [...], a little scared, shy, not used in big countries" (Delta, 2007a, p. 319). At Christmas 1907, in Frankfurt, the children sang Greek songs with their 'Greek teacher' and foreign songs with their 'foreign female teachers' (Delta, 2007a, p. 335). In summer 1908, she mentioned excursions with the children and their teacher (Delta, 2007b, p. 457). In 1911, she states: "But in the evening, children would come from the garden, with their new, silly Greek teacher, who had come to Kronberg from Serres, to replace the first who had left to get married, and my girls do not love her at all" (Delta, 2007b, pp. 733-734).

\subsubsection{Schooling and homeschooling in Alexandria of Egypt}

For the successors of the author's generation, gradually, homeschooling will be replaced with education in schools. Emphasis was given to the attendance at the Greek schools and the learning of the Greek language. Meanwhile, the Greek community in Egypt gradually declines, while the interest in returning to Greece is growing. The orientation to massive education in schools became a reality. The training in school wins the lead (Politis, 1928).

Delta gives the evidence that since the years of her childhood, things have changed for Greek education in Egypt: "the teachers improved, and the school level was higher even from those of the Greek state schools, and all our nephews attended these schools and learned Greek thoroughly. But, the improvement of our schools, for boys and girls, had benefits for the next generation" (Delta, 2008, pp. 197-198).

However, in winter 1913-1914, in Alexandria, Delta mentions that the girls were gathered in the dining room with their French female teacher (Delta, 2007b, p. 330).

\subsubsection{The Cultural knowledge preponderance}

It is stated that the second generation of the Greek upper bourgeoisie of diaspora in Russia "will follow an already rigged and prosperous business and needed special training. So, along with many other successors of merchants from Mytilene, attended the School of Commerce of Marseilles and other famous schools, as this of Halki. However, the third successive generation has a more European focus on its studies. They studied in the best universities of Europe, in Cambridge, 
Paris, Berlin and Dresden. It was the generation of bourgeois prepared completely for shouldering the leading role reserving for it in the 20th century" (Sifnaiou, 1996, p. 286).

Similarly, the Greek children of upper bourgeoisie in Egypt, of the successor to Delta generation, is aptly argued that "at first they started with the Greek community school (elementary, high school) and then continued their studies abroad (England, France, Switzerland) in more specialized educational directions. Now, education has nothing to do with the elementary literacy or with having an expert technical knowledge that will support the business, but expands to other fields. Over the years the children of these families, apart from business and law, specialized in philosophy of religion, in the School of Fine Arts (École des Beaux-Arts), in the School of Applied Arts (École des Arts Appliqués) and socialized with people who were in high level regarding the culture, the art and the music creation. It is obvious, that this is an education which responds to a new world coming" (Tomara-Sideris, 2004, pp. 210-211).

However, the interest in higher education in the capitals of Western Europe remains undiminished. Instead, the focus on business studies, that guaranteed the worthy succession in the family business, decreases, while the interest in studying 'culture' and 'arts' is increasing. This interest will be reflected in the establishment of museums by the descendants of this upper bourgeoisie, in the 20th century in Greece. In 1929, Antony Benakis founded 'Benakis Museum', the oldest museum in Greece operating as a Foundation under Private Law (Tomara-Sideris, 2004, pp. 102169; Benaki Museum, 2015). However, we should notice that the cultural knowledge and representation, and the "cultural capital' could be linked with the social position and the 'economic capital' (Bourdieu, 2002).

\section{Discussion}

Alexandria was a cosmopolitan city, with foreign communities of diaspora and with constant communication with the major urban centers of Europe. In architecture, in late 19th century, in Egypt also, the European Neoclassicism prevailed. And particularly, a unique style, the Mediterranean neoclassicism, which was succeeded by the European eclecticism. In the upper bourgeois houses, the varied architectural styles followed European trends (Topis, 2002). The Greek bourgeoisie imitated the culture of the European bourgeoisie (Karanasou, 1999). European was also, the trend in education of the Greek upper bourgeoisie, which constituted a limited leading elite, and followed the upper bourgeoisie of other countries which imitated the nobility's education. 'Homeschooling' was of main importance and the instructors appointed, were mostly from Western Europe.

Indicative is that Mrs. Vlastos in France, Marseille sends a French governess to her sister in Egypt Alexandria. Interesting is also, the testimony of Delta for the German governesses sisters Berg, which had worked in many of the Greek houses of Istanbul and Alexandria, and they were sought after. Delta's autobiography shows the way that the networks of relatives and the networks of communication functioned, within the upper Greek bourgeoisie diaspora, which lives in the Ottoman Empire, Constantinople and Egypt. This communication seems to be very developed due to kinship and business ties. The Greek upper bourgeoisie diaspora shaped a common culture in relation to the upbringing and the education of their children. The Greek upper bourgeois, in late 19th century, in Greece and in diaspora constitute leading social elites with a distinguished education from other social groups.

The flourishing of the Greek Upper bourgeoisie of diaspora was linked to the European colonial domination. Homeschooling is a main feature of colonial education. Home education gives the flexibility to travel or live in multiple locations. As a cosmopolitan elite, they followed the international principles of upper bourgeoisie education with main feature the private character of education. Penelope Delta mentioned 'nurses', governesses and full-time and part-time tutors with Austrian, Italian, French, English and Greek origin. The 19th century is the century of nationalisms. Also, negative ethnic stereotypes are detected between foreign teachers and students and their families as well as between foreign teachers of different nationalities.

Findings show, that Delta was taught curricula at home, followed the habits of urban families of the era. Of main importance were private tutors, who taught in the study room. The courses aimed mainly at the learning of foreign languages, which were necessary in commercial activities, the frequent migrations due to work commitments and the social life with distinguished social events and travels. The learning of the Greek language and their Greek education faced the obstacle of katharevousa (purified) Greek, a language that only a Greek elite could use. The Greek was of secondary importance. The author describes her homeschooling routine. Children followed a strictly planned programme: foreign languages, French and English, Greek, namely the katharevousa, general schooling, holy indoctrination and reading, arts, music and piano, painting, dancing and crafts. Home schooling was very popular within the upper Greek bourgeoisie of diaspora and in Greece. Articles published in Greece criticize this educational approach. They argue that it is not good for the national conscience. They believe that this education was due to social imitation in this distinguished 
leading social elite. However, it is obvious that also, foreign governesses facilitated the learning of foreign languages from a very early age.

The parents were very strict regarding order and discipline. They spent very little time with their children. While emphasis was placed for both genders on good social behavior and discipline issues. This strict parenting had prioritized children's education and significant amounts were spent for teachers and schools. Girls' education was continued at home while for the boys good schools were selected. For the upper bourgeoisie a common educational practice was the migration of their sons for educational purposes, mainly in Western Europe, where they remained as boarders. Their education was multicultural, cosmopolitan and oriented to Western Europe. And, mainly, in the big European cities.

The Greek upper bourgeoisie invests, also, in donations to community schools for, making easier to compatriots to be educated and improve their social status through education. And she provides distinct education to its children, in order to maintain a distinct social status. At the same time, scholarships, for study and research for children of lower social classes, contribute, facilitate social advancement breaking barriers between social classes.

The new generation of the Greek upper bourgeoisie of Egypt, the children and nephews of P. Delta, were oriented more to the massive school education. They placed more emphasis on learning the Greek language. Their studies invariably had a European orientation. The focus on commercial and business studies was replaced by the preponderance of studies on culture.

\section{References}

Anagnostopoulou, D. (2005). Aspects of identity and otherness. The image of the other in modern Greek novel. In R. Tsokalidou \& M. Paparousi (Eds.). Identity's issues in the Greek diaspora, Language and literature (pp. 233-242). Athens: Metaixmio.

Archives des Frères Maristes, Doc. 686.021 06, lettre du Frère Germain, février 1911.

Bakalaki, A., \& Elegmitou, H. (1987). The domestic education and the feminine homework, From the foundation of the Modern Greek State until the educational reform of 1929. Athens: IAEN.

Bayley, S. (2014). The English Miss, German Fräulein and French Mademoiselle: foreign governesses and national stereotyping in nineteenthand early twentieth-century Europe. History of Education: Journal of the History of Education Society, 43(2), 160-186.

Beckert, S., \& Rosenbaum, J. (Eds.), (2010). The American Bourgeoisie: Distinction and identity in nineteenth century. N.Y.: Palgrave Macmillan. Benaki Museum. (2015). Retrieved from http://www.benaki.gr/index.asp?lang=en

Berelson, B. (1952). Content Analysis in Communication Research. N.Y.: Free Press.

Bourdieu, P. (2002). Distinction. A social critique of the Judgment of taste. Athens: Patakis.

Clogg, R. (2003). A concise History of Greece. (2nd ed.). Athens: Katoptron.

Cohen, L., \& Manion, L. (1994). Research Methods in Education (4rth ed.). London \& N.Y.: Routledge.

Delta, P. (1961a). The Irresponsible or Children's Souls. In P. Delta. The Irresponsible, Reflections (pp. 1-200). Athens: Estia.

Delta, P. (1961b). Reflections on the Upbringing of children. In P. Delta. The Irresponsible, Reflections (pp. 201-251). Athens: Estia.

Delta, P. (1980). Trelantonis (Crazy Antony). (16th ed.). Athens: Estia.

Delta, P. (1994). Memories 1899. (2nd ed.). Athens: Hermes.

Delta, P. (2007a). Memories 1921. Athens: Hermes.

Delta, P. (2007b). Memories 1940. Athens: Hermes.

Delta, P. (2008). Raw remembrances. Athens: Hermes.

Delta, P. (2013). Mangas (Crafty). (30th ed.). Athens: Estia.

Delta, P. (2014a). Romiopoules, The Awakening (Vol. 1). Athens: Hermes.

Delta, P. (2014b). Romiopoules, The Heat (Vol. 2). Athens: Hermes.

Delta, P. (2014c). Romiopoules, The Dusk (Vol. 3). Athens: Hermes.

Dertilis, G. (1991). The Hellenism of Diaspora and the bourgeoisie of Greek State. In G. Dertilis, \& K. Kostis (Eds.), Issues of Modern Greek history, 18th-20th century (pp. 145-161). Athens \& Komotini: Ant. N. Sakkoula.

Dertilis, G. (2010). History of Greek State, 1830-1920 (Vol 1 \& 2). Athens: Estia.

Dimaras, A. (2006). Penelope Delta and educational demoticism: The case of reading books (1913-1918). In A. Zannas (Ed.), Modern approaches to her literature work (pp. 147-191). Athens: Estia.

Fragouli, A. (1998). The history of the Egyptian Hellenism and its education: 16th-20th century. Athens.

Gialourakis, M. (2006). The Egypt of Greeks: Brief history of Hellenism in Egypt. Athens: Kastaniotis.

Hadjifotis, I. M. (1999). Alexandria: two centuries of modern Hellenism (19th-20th century). Athens: Ellinika Grammata.

Jensen-Wallach, J. (2006). Building a Bridge of Words: The Literary Autobiography as Historical Source Material. Biography, 29(3), 446-461.

Karanasou, F. (1999). The Greeks in Egypt: from Mohammed Ali to Naser, 1805-1961. In R. Clogg (Ed.), The Greek Diaspora in the Twentieth Century (pp. 24-57). Hampshire and London: Macmillan.

Kardasis, B., \& Harlafti, T. (2006). Seeking the countries of promise: emigrant Hellenism from the mid-19th century until World War II. In I. Chassiotis, O. Katsiardi-Hering, \& E. Ambatzi (Eds.). The Greek diaspora 15th-21st century (pp. 53-73). Athens: Greek Parliament.

Kibler, R. (2013). Girls' Education in Eighteenth Century France: The Development of Feminine Passivity. Through Gendered Lenses, University of Notre Dame, 9-25. Retrieved from http://genderstudies.nd.edu/assets/100725/through_gendered_lenses_full_text.pdf

Kitroeff, A. (2010). North Africa - Middle East. In K. Loukeris \& K. Petraki (Eds.). The Roads of the Greeks (pp. 187-221). Athens: Polaris.

Kouzeli, X. (2005). Text and picture: The game of distances. The illustration of P. S. Delta's books (Thesis). Rodos: University of the Aegean. 
Kyriazi, N. (2011). The Sociological Research, Critical Overview of Methods and Techniques. Athens: Pedio.

Leccou, P. (2001). The Averofian Gymnasium - Lycee (High School) of Alexandria from its foundation until 1960 (Thesis). Thessaloniki: Aristotle University of Thessaloniki

Leccou, P. (2004). The Averof High School of Alexandria, from its foundation until 1960. Thessalonica: Ziti.

Lidbury, C. (2013). Elinor M. Brent-Dyer's Chalet School Series: Literature as an Historical Source. Children's Literature in Education, 44, 345358.

Loukatos, S. (1994). Diaspora Hellenism, Historical critical essay. Athens.

Maeder, A. (1993). Gouvernantes et précepteurs neuchâtelois dans l'Empire russe (1800-1890). Neuchâtel: Université de Neuchâtel.

Malafantis, K. (2005). Pedagogy of Literature (Vol. 2). Athens: Grigoris.

McAdams, D. (2008). Personal Narratives and the Life Story. In O. John, R. Robins \& L. Pervin (Eds.), Handbook of personality: Theory and research (3rd Ed., pp. 242-262). NY: Builford Press.

Milios, G. (2000). The Greek social formation. From expansionism in capitalist development. (2nd ed.). Athens: Kritiki.

Murinová, K. (2007). The Character of Governesses, Guardians, Chaperons and Nurses in British Novels. M.A. (Thesis). Masaryk University Faculty of Arts.

Navet-Grémillet, M.-C. (1998). Pénélope S. Delta et Alexandrie, Une Femme Grecque à la confluence des langues et des cultures. Thèse de doctorat, Montpellier: Université Paul Valéry-Montpellier III. Identifiant BU: 98MON3008. Retrieved from http://www.diffusiontheses.fr/68264-litterature-neo-hellenique-16-19eme-siecles

Navet-Grémillet, M.-C. (2006). Pénélope S. Delta, the Alexandrine. In A. Zannas (Ed.), Modern approaches to her literature work (pp. 313-335). Athens: Estia.

New guide of biographies of Modern Greek and contemporary writers (Vol. 2). (1979). Athens: Dyros.

Papakostas, G. (2000). Fotis Fotiadis and the 'Brotherhood of the National Language'. (4th ed.). Athens: Estia.

Peterson, M. J. (1970). The Victorian Governess: Status Incongruence in Family and Society. Victorian Studies, 14(1), 7-26.

Pilbeam, P. (2009). From Orders to Classes European Society in the Nineteenth Century. In T. C. W. Blanning. The Oxford Illustrated History of Modern Europe (pp. 141-175). Athens: Touriki.

Politis, A. (1928). Hellenism and Modern Egypt (Vol. 1). Athens-Alexandria: Grammata.

Russell, J. (1877). At home or in public schools should be educated young people? Estia, 78, 412-413.

Santos, N. M. W. (2005). Na intimidade das letras: história e representações de loucura no romance simbolista de Rocha Pombo. Textura Canoas, 12, 23-35.

Sifnaiou, R. (1993). Lesvian immigrants in Russia. The case of Sifnaios Brothers. Lesviaka, 14, 183-197.

Sifnaiou, E. (1996). Lesvos, Economic and Social History (1840-1912). Athens: Trochalia.

Skårdal, D. B. (1984). "Hard' facts and 'Soft" sources: Literature as historical source material? American Studies in Scandinavia, 16(2), $72-79$.

Spathakis, A. (1889). Household pedagogy or for the home education of children for the use of parents. ... and educated young women in the Schools for girls. Athens.

Stamatopoulou-Vasilakou, Ch. (1994). The Greek Theatre in Constantinople in 19th century (Vol. 1). Athens: New Cycle Konstantinopoliton.

Stavros, I. (1912). Pedagogical Issues, dedicated to Mrs. Sophia Schliemann. Haravgi, 2(40), 137-138.

Symonolewicz, C. (1944). Autobiography as a source for historical and sociological studies of Polish immigration. Polish American Studies, 1, 1721.

Taxis, Oi. (1909). A concise history and topography of Lesvos (2nd ed.). Cairo: Printing Press Politou.

Terzis, N. (2010). A Study of Modern Greek Education, Before the state - Out of the state - In the state. Thessaloniki: Kyriakidis Brothers.

Tomara-Sideris, M. (2002). Benefaction and personality. Benefactors Greeks of Cairo. Athens: Papazisi.

Tomara-Sideris, M. (2004). Families of Alexandria: Choremi - Benaki - Salvagos. Athens: Publishing House Corfu.

Tomara-Sideris, M. (2007). The Greeks of Cairo. Athens: Publishing House Corfu.

Tomara-Sideris, M., \& Theocharis, Th. (2008). Quartier Grec: a town within the town. Paper presented at the Seventh International Conference on Urban History: European City in Comparative Perspective, Panteion University, Athens - Piraeus, Greece, 27-30 October 2004, Session: The urban and local history of social policy (XIX-XX centuries).

Topis, A. (2002). Alexandria, times, places and persons who were once. Athens: Kedros.

Trimi-Kyrou, K. (2003). The New Diaspora, Greek communities in Egypt. In History of Modern Greece (Vol. 5, pp. 373-382). Athens: Ellinika Grammata.

Tselika, B. (2004). Penelope Delta, life narrative. Athens: Museum Benaki \& Olkos.

Tsirkas, S. (1983). Kavafis and his era. Athens: Kedros.

Tsoukalas, K. (1992). Dependence and reproduction, The social role of education in Greece. Athens: Themelio.

Tziovas, D. (2009). Greek Diaspora and Migration since 1700: Society, Politics and Culture. Farnham, Burlington: Ashgate.

Van Zanten, A. (2010). The sociology of elite education. In M. Apple, S. Ball, \& L. A. Gandin (Eds.), The Routledge International Handbook of the Sociology of Education (pp. 329-339). London \& N.Y.: Routledge.

Veremis, Th., \& Koliopoulos, G. (2006). Hellas. Modern continuum. From 1821 until today. (5th ed.). Athens: Kastaniotis.

Vitti, M. (2008). History of Modern Greek Literature. Athens: Ulysses.

Vlachou, E. (1991). Trading Companies established in Mytilene, Constantinople and Egypt through the deeds of the Greek sub-Consulate of Mytilene. Lesviaka, 13, 85-108.

Wadsö-Lecaros, C. (2001). The Victorian Governess Novel. Lund: Lund University Press.

Zannas, A. (Ed.). (2006). Penelope Delta and her world. Athens: Museum Benaki.

Zannas, A. (2008) Introduction. In P. Delta. Ion Dragoumis (pp. 9-20). Athens: Hermes.

Zannas, P. (2009). Introduction and Timeline. In P. Delta. Eleftherios Venizelos, Calendar-Memories, Testimonies-Correspondence (pp.7-55). Athens: Hermes. 